\title{
ANTI-SEMITISM IN FEMINISM: RETHINKING IDENTITY POLITICS
}

Bernice Hausman

IN THIS PAPER I will discuss a particular instance of what has come to be called the "anti-racism/anti-Semitism debate." I offer this analysis as an intervention into anti-racist feminist political struggle, both in terms of my own attempts to understand that struggle and the attempts of the movement at large to conceive of its principles and protocols. It is my hope that the knowledge I produce here will contribute to the ongoing task of reconstructing feminism's history, in addition to augmenting the growing body of feminist theory which informs current political action. In this paper, I speak as a Jewish woman who is trying to conceptualize a politics that neither rigidifies nor ignores that identification.

In 1982-83 experiences concerning racism, anti-semitism, and Zionism split the editorial collective of Spare Rib, a British feminist magazine, irrevocably altering both the political direction of the magazine and the make-up of its editorial staff. The significance of this explosive series of events lies not only in the importance of the anti-semitism/anti-Zionism/racism debate, but also in that it caused the editors to confront their own collective protocols, including issues such as censorship and editorial authority. A debate over the collective's handling of the issue raged for more than a two year period in the pages of the magazine itself. In dealing with anti-semitism, anti-zionism and racism, Spare Rib became an arena for the fight over the changing nature of feminism and feminist politics.

The first two articles I was able to find that considered these issues were markedly pro-Jewish: both preceded Israel's invasion of Lebanon on June 6, 1982. In August of 1982 "Women Speak Out Against Zionism," an interview with three women-one Lebanese, one Israeli, and one Palestinian-addressed the Israeli invasion of Lebanon with a discussion of the connections between Zionism and anti-semitism, in an attempt to distinguish between anti-Zionism and anti-semitism (Boyd 22-23). All three women spoke of the difficulties of being 
anti-Zionist while trying not to appear anti-semitic, and they referred to the early Zionists-manipulation of anti-semitic philosophy to press for a homeland (22). By connecting Zionism to anti-semitism, they implicitly aligned anti-Zionism with a pro-Jewish politics which was nevertheless critical of Israeli imperialism and sympathetic with the plight of the Palestinian people. They also mentioned the existence of Palestinian Jews in Lebanese refugee camps and the oppression of Oriental Jews by Ashkenazi Jews within Israel in order to emphasize that the racism of official Israeli policies was in fact separable from its Zionism.

This article precipitated the debate that was to engage the magazine on and off for the next few years. Immediately, however, it motivated the West London Jewish Lesbian Feminist Group to write "About Anti-Semitism," published in October 1982. This article defined anti-Zionism as both anti-semitic and non-feminist, arguing that feminists were not responsible for governmental policy. Made up of various testimonies, "About Anti-Semitism" attempted to refute the idea that Jews were members of the dominant class and emphasized Jewish women's silence about their experience as Jews within feminism. Resisting the imperative to identify themselves as anti-Zionist in order to credential themselves as feminists, these women spoke of their conflicts as Jewish feminists in an anti-semitic movement:

On the one hand being a feminist means demanding the space to become more articulate about my own oppression and trying ways of taking over my own life. On the other hand, as a Jew I am silenced precisely on these issues. In fact, as a Jew, these issues are reinterpreted for me. (20)

The next month Spare Rib published an article by a group calling itself Women For Palestine. This article, "Women Against Zionism," contained an account of Israeli atrocities in Lebanon and argued that Jews should be held accountable for Israeli imperialism. Women For Palestine denounced Zionism as a movement which capitalized on European anti-semitism (rather than struggling against it) in order to gain its "homeland," and they refuted its status as a liberation movement. They pressed for the establishment of a democratic Israeli/Palestinian state and denounced Israeli militarism.

"Women Against Zionism" caused a flood of letters from Jewish feminists in support of Israel and/or against the perceived antisemitism of the article. The editorial collective, which was at this time integrating itself by inviting a number of women of color to join the staff, debated whether or not to publish the more than forty letters. Stymied by their inability to come to a consensus, the editors did not publish the letters, but in an editorial (Spare Rib 126) opened up the magazine as an arena for "debate, criticism, and struggle" over the 
issues of Zionism and anti-semitism. They themselves wrote, "we are searching for a militant way of opposing anti-semitism here and now, and of opposing any imperialist oppression of the Palestinian people today" and supplied a set of eleven questions regarding the issue and how to address it. In the editorial of the May 1983 issue (Spare Rib 130) the collective revealed their decision not to publish any of the letters received after the "Women Against Zionism" article, because although the collective was not exclusively anti-Zionist they were as a group pro-Palestinian and felt that they could not publish letters which ignored the position of the Palestinians. They reiterated the connections between Zionism and nineteenth-century European antisemitism, stating that anti-Zionism was not necessarily anti-semitic.

This editorial provoked a number of letters published in the following issues (Spare Rib 131 and 132) that accused the editors of silencing Jewish feminists, especially those who had expressed criticisms of Israeli politics and the desire for a dialogue over the issues. There were also a number of letters in these two issues that supported the Palestinians and called for the end of Israel. The July issue also contained an article written by the collective in which the members discussed the events of the past months and revealed the tensions that had erupted within the collective over the censorship of the Jewish women's letters. In the article, "Sisterhood . . . is plain sailing" (Editorial collective), each member of the editorial collective expressed her position on the issue; the statements by the women of color were set off in a box in the center of the article.

Essentially, the collective had split along race lines over whether to publish the letters of response to "Women Against Zionism;" the women of color claiming that (1) anti-semitism was a white women's issue (and therefore that its predominance in Spare Rib testified to the white orientation of the magazine) and that (2) Third World women needed to struggle together with Palestinian women. Susan Ardill, a white editor, while basically defending Spare Rib's now outspokenly anti-Zionist position, expressed her belief that the magazine should be a space where conflicts could surface and be discussed. This article also revealed that the collective met separately for a few months, one group of women of color and the other of white women. (By this time the Jewish women had left the collective, although this was not revealed in this particular article.)

In the letters' section of the September issue (Spare Rib 134) the readership expressed their opinions concerning the magazine's new emphasis on anti-racist and international politics; an orientation which was a direct outcome of the inclusion of women of color on the editorial collective. A few readers expressed dismay at the political 
transition, one women's group writing that they did not consider racism to be an issue of central concern to feminists and that they were saddened to see Zionism prioritized within the movement. Another reader identified Spare Rib as an international anti-racist magazine rather than a feminist magazine. Yet another decried the polarization caused by the representation of Palestinians and Jewish feminists as monolithic categories. The rest of the 1983 issues contained similar responses to the conflict, after which the controversy died down. Spare Rib continued its transformation into a globally-oriented, anti-racist feminist magazine, and the furor surrounding its rebirth waned.

In September 1984 Spare Rib published an article by Nira YuvalDavis, entitled "Zionism, Anti-Semitism and the Struggle Against Racism: Some reflections on a painful debate among feminists" (all citations are from the partial reprint in Connexions 19, except where noted), in which the author, a Jewish feminist, attempted to address the issues left unresolved the year before. Assessing the original relationship between anti-semitism and anti-Zionism, she articulated the distinctions between the two (refuting earlier articles that had represented them as ideologically similar), while also demonstrating that because Zionism was a response to European anti-semitism, it necessarily "shares some of the major assumptions of that which it opposes" (7).

Significantly, Yuval-Davis discussed the way in which the women of color in the Spare Rib collective represented anti-semitism as a "white women's issue." In this instance she called on feminists to rethink their position that racism is always a politics of color and of economic exploitation. While not denying that black Britons were "the primary victims of British racism today," she noted that "the definition of the colour is social and historical, not biological," because "skin colour and other characteristics" are not really important in themselves; they are just the means of identifying the objects of racist discrimination and oppression" (8). (By way of this analysis, she agreed that the United Nations resolution defining Zionism as a racist ideology was correct.) Although "racism is about power relations between collective groups, and is one of the most forceful means by which one group excludes another," "these power relations do not necessarily coincide with economic relations" (8). By calling for an anti-racist politics that would take into account Jews' relative economic affluence, their status as a predominantly white group in European culture, and their experience of anti-semitism as a racism, Yuval-Davis challenged feminists to reconsider economic exploitation and color as the only significant factors in racist discrimination (although they differentiate the experience of the oppression and its ultimate effects). 
In the end, Yuval-Davis pointed to the "politics of experience" as the major problem in this debate, writing that "if done uncritically, it can develop into extreme relativisation-there is no valid criterion from which to judge between the different perspectives developed by women who have undergone different personal experiences" (9). Declaring that "there exist real divisions and relations of oppression and exploitation among women" (9), she abandoned any simplistic notion of sisterhood in order to advocate a politics that struggles against both Palestinian oppression and anti-semitism, in which women's differences are taken into account in the context of the struggle itself. While her conclusions might seem utopian and some of her stances contradictory, Yuval-Davis succeeded in addressing and complicating most of the issues that had plagued the magazine in the preceding two years, and she did so by drawing attention to the problems attendant to feminist process itself: the acceptance of every woman's "experience" as political theory, the unproblematic shifting of politics from the consciousness raising group to the international arena, and the inadequate attention to the complexity of relations between and among different women.

After September 1984 coverage of the issue of anti-semitism within feminism literally stopped in Spare Rib, while articles on Palestinian women, the situation on the West Bank or Gaza, and Israeli policy appeared sporadically. It was not until November 1987 that another Jewish feminist opened up the debate: Jenny Bourne's article "Homelands of the Mind: Jewish Feminism and Identity Politics," originally published in Race and Class, was excerpted and reprinted in Spare Rib as "Jewish Feminism and the Search for Identity." (I use the longer, more theoretical, original article in this analysis.) Bourne followed Yuval-Davis in assessing not only the issue of anti-semitism within the feminist movement, but its significance to the feminist movement: in analyzing the issue and, in particular, analyzing Jewish women's responses to anti-Zionist feminism, she formulated an argument against identity politics as a problematic ideological tendency within feminism.

Writing as a Jewish feminist and as a marxist, Bourne argues that "identity politics" within feminism caused a shifting of the framework of the analysis of racism from exploitation to oppression. Thus:

The politics of equal oppressions, in sum, is ahistorical in that it equates oppressions across the board without relating each to its specific history, and so severs racial and sexual oppression from class exploitation, divorces the black experience from the Third World experience, dismembers racism from imperialism, and attempts, by some magic alchemy of the soul, to transmute the political terrain of the material world into homelands of the mind. (16)

The tendency in the movement was to shift considerations of exploi- 
tation (material oppression or discrimination) to considerations of intra- and inter-personal oppression. ${ }^{1}$ When the Israeli occupation of Lebanon threw the problem of Zionism, Israeli imperialism, and Palestinian struggle onto the feminist table in 1982, Jewish feminists themselves responded by shifting the terms of the debate to Jewish feminist identity and anti-semitism within the feminist movement. Bourne called attention to Jewish feminists' refusal to take up the challenge of Israel as both Jews and feminists, and criticized their political distancing from the problem as such, a move that allowed them to refocus on internal, localized questions based on their particular, immediate "experience." Thus, the international conflict posed by Israel's imperialism was transformed by Jewish feminists into an identity crisis for feminism.

Ultimately, Bourne questioned the ability of Jewish feminists to define the terms of their struggle against anti-semitism. By repeatedly asserting the necessity to respond to an Israel that justified (and continues to justify) its activities in the name of all Jews and Jewish survival, she emphasized that Jewish activists must engage in the situation as it is given to them and that to shift the debate from Israel to feminist anti-semitism was to avoid the complexities of all Jews' relationship to Israel. Since the politics of oppression encouraged its adherents to focus on naming their particular oppression and constructing their specific identity, it denied the material aspects of discrimination and with it the structural component to racial inequality. Jews, in her analysis, did not have a choice to act or not to act in response to Israel's invasion of Lebanon, because Israel, that is, takes a position for us and, in failing to disown it, we tacitly agree to its politics. Our non-position on Israel is effectively a position. And each time the Women's Movement has taken a stand against Israel, or for Palestinians, we have countered with a plea for solidarity with us (6).

In this materialist analysis, Jewish feminists are urged to confront the historical specificity of the current situation, which demanded a specifically Jewish feminist disavowal of Israeli policy, rather than a disassociation from Israel as a male-dominated nation state (which occurred in some quarters) or a defense of Israel as essential for Jewish survival (which occurred in others). In the end, Bourne castigated feminist identity politics as maintaining feminism as an inward-looking and hermetic political movement, focused on its particular identity as such (or the identities of its "adherents") rather than what it could do with those identities once they were defined.

Taking issue with the equivalences made between racism and anti-semitism, Bourne accused feminism of

dilut[ing] the meaning of racism itself by personalising it. Racism has ceased to be 
seen as the primarily structural and institutional issue that it was shown to be in the 1960s and 1970s and has become, under the impact of tendencies in the Women's Movement, an internalised matter of prejudice. . . Power then becomes primarily a personal issue between individuals . . . and not the way an exploitative system is hierarchically structured so as to get maximum benefit from maximum differentiation. (14)

This tendency led to the conception of racism as an ideal category, and its theoretical separation from material conditions, resulting in the facile and erroneous analysis of Jewish oppression as the same as or equivalent to anti-black discrimination. In western Europe, while anti-semitism might have been essential to the structure of the feudal state,

capitalist societies were founded on anti-black racism-through slavery and colonialism - and still depend upon the exploitation of non-white peoples, both at home and abroad ... [and] we do not now face in western societies the type of systemic exploitation which relegates black and Third World people to the "lower depths" and threatens to keep them there. (14-15)

By refusing to analyze structural inequality based on racial discrimination, and by ignoring the historical specificity of racial and ethnic exploitation, Jewish feminists erased the very differences that must be accounted for in order to construct a workable coalition between themselves and feminists of color.

Bourne's account of the implications of Jewish feminists' responses to the anti-semitism/Zionism/racism debates is rich and insightful, urging us as it does to confront a tendency within feminism that (at this point at least) seems inherent to feminist political practice. She countered the position of the Combahee River Collective- "The most profound and potentially the most radical politics come directly out of our own identity as opposed to working to end somebody else's oppression" (quoted in Bourne, 2)-by suggesting that, if anything, Jewish feminists could offer (and have offered, in many instances) their cultural legacy as Jews precisely in order to aid in the fight against other people's oppressions and that the insistence on the possibility of another Jewish holocaust as justification for support of Israel revealed a blindness to other holocausts currently in process. This analysis inverts the popular understanding that identity shapes politics into a notion of a politics which forms identity: "We can only learn and confirm our identity, in other words, through our actions. What we do is who we are" (original emphasis, 22).

Insightful as it is, Bourne's analysis fails to account for the censorship of Jewish feminists by the Spare Rib collective and the debate in the magazine over how to deal with an issue such as this one. What is interesting about the problem posed by the Jewish feminists' response to the collective's pro-Palestinian stance lies not only in the way in 
which it highlights the problematic shift to the politics of identity within feminism, but also in the way in which it forced the members of this particular feminist collective to question and reformulate their editorial protocols. It is significant that an explosive international issue became the focus of both a general debate within the movement, and a specific controversy for the editors of Spare Rib, because it demonstrates the ways in which political differences work themselves out materially.

In this case, the integration of the collective upset the consensus procedures to which it had formerly adhered when the women of color refused to compromise on an issue they defined as racist. Many readers wrote in that they were upset that the women of color had been given "veto" power over the publication of the Jewish feminists' letters; as Juliet Pope wrote in an article, "Anti-racism, anti-Zionism and anti-Semitism: Debates in the British Women's Movement," the censorship violated the tradition of freedom of speech within the feminist movement. Susan Ardill, in the editors' article, "Sisterhood ... is plain sailing," had asked that readers understand the collective's attempts to work in a mixed race environment, in which the white women needed to give up some of their power to define and articulate certain issues (Editorial collective 27). Clearly, however, both readers of the magazine and members of the collective were uncomfortable with the changes in protocol that seemed necessary in order to make that transition to an integrated editorial staff. Women of color were "given" the last word on racism within the magazine, a phenomenon unheard of within the feminist movement, where women had heretofore conceived of themselves as an harmonious group.

Pope claimed that "It was unprecedented for women to be pressed to define their political allegiances outside the Women's Movement" (22) and that many felt that the "autonomy" of the movement was threatened by male-dominated, left political priorities (18). A similar sentiment was expressed by Irene Tinker in her review of the U.N. Mid-Decade Conference for Women in Copenhagen - that attention to the Palestine issue "diverted energy from the real point of the conference: women's status and welfare" (531). Many feminists felt that "their" movement was losing its specificity as a women's movement, as it began to articulate a more internationalist, anti-racist political commitment. Thus, while "anti-Zionism appears to have provided a locus around which feminists of different political persuasions, and especially anti-racist and socialist feminists, could rally" (Pope 15-16), many feminists were concerned "that the debate over Zionism had entailed the violation of basic feminist principles" (18).

The anti-Zionism debate also forced feminists to acknowledge the 
"contradictory elements" within the Women's Movement, which had been founded on the notion that "A certain degree of harmony - or at least a recognized unity of purpose-was . . . a precondition and not a consequence of sisterhood" (Pope 23). The emotions evident on the pages of Spare Rib reveal the anti-Zionism/anti-semitism/racism debate as one specific discourse through which feminists articulated their ambivalences about the changing nature of the movement itself. This is not to say that the issue itself was not important, but that it represented a larger conflict-a debate over the fundamental principles of and issues within feminism.

Perhaps it was not the first time, but in a most spectacular way, feminism found itself acting in a manner similar to the other political groups (like the new left) from which it had differentiated itself: censoring the members of an "out" group, bickering over issues of power in what had been collective decision-making processes, and fragmenting as a result of unresolvable political differences. As consensus broke down, it was clear that differences between and among women had merely been masked within the movement. When the women of color refused to print letters that they considered racist, they were responding to more than just the specificity of a situation they considered racist, but to years of exclusion themselves. Censorship was central to the controversy within the Spare Rib collective, because the issue highlighted power differences among feminists, in this case in terms of who decides what gets printed. Jewish womenrepresented in the movement in numbers well above their proportion in the general population-experienced their "fall" from positions of relative "power" within the movement partially through their inability to define the issue of anti-Zionism/anti-semitism in their favor.

In the terms of Jenny Bourne's analysis, Jewish feminists responded to this perceived attack by labeling it anti-semitic in order to avoid the challenge of confronting the imperialism of Israeli politics and acknowledging their silent complicity with Israeli racism. While the Jewish feminists' response was clearly inadequate in terms of materialist, anti-racist politics, it was convenient to locate the tensions arising between white feminists and feminists of color at this particular moment in the Women's Movement as a controversy between black and Jewish women. Whereas, all white women were experiencing a destabilization of their positions within feminism due to the realization that the movement had not eradicated racism from within its purview. As women of color integrated the movement, changing as a matter of course both the terms of its debate and the protocols of that debate, much of the conflict was articulated as a problem between black and Jewish feminists over the issue of anti-Zionism and anti- 
semitism. The question that we must ask today, as the fallout from this controversy continues to influence anti-racist politics in the movement, is why two "out groups"-one with substantial material advantages and power over the other, but both marginalized within western society as a whole-became the central protagonists in a struggle that ought to have included a larger ensemble of actors.

Within the context of the Spare Rib controversy, the abovementioned article "Sisterhood ... is plain sailing" (Editorial collective) reveals some of the ways in which these power issues "shook out" in practice. In the prefatory statement to this article, the collective wrote that they could not come to any collective agreement about the issues (24). In the article itself, only the white members signed their statements, while the women of color presented theirs in a block marked off from the others and without individual signatures. At this point, since the Jewish women had already left the collective, the conflict circulated amongst the non-Jewish white women and the women of color. The latter group made it clear, however, that their antagonism toward the letters from Jewish women had to do, in part, with the perceived stature of Jewish women within feminism. For example, one statement implied that Jewish feminists had power insofar as they were able to maintain the issue of anti-semitism as central to the racism debate.

However, the issue was not only that Jewish women held positions of authority within feminism (or were able to draw attention to themselves and keep it there), but that the women of color joining the Spare Rib collective were forced to deal with an issue that predated their tenure on the collective and which they considered a cut-anddried matter of white imperialism on a Third World people. Thus, the unasked question which motivated much of the anger in their comments was "what do (you) white women want from us?" Brought into the collective through affirmative action (a policy toward which they maintained a measured skepticism), the women of color felt that the issue taking up the vast majority of their energy had been defined and prioritized before their arrival and that the insistence of the white women on the collective to pursue it was symptomatic of white feminists' inability to give up their power to define the "collective" agenda.

This anger was directed not only at the (non-Jewish) white editors, however, but at Jewish feminists in general, to whom a "great power" was ascribed. It is this shifting emphasis-from conflicts within the collective process due to racial integration of the editorial staff to the scapegoating of a group within the larger movement - that marks the difficulty of any analysis that attempts to figure out "what was really 
going on." There was an overdetermination of issues that makes any attempt to pin down the cause of or solution to the conflict reductive and counterproductive. Each group that identified itself as party to the controversy was convinced that their experience within it was symptomatic of the "real problem"; thus, the Jewish women claimed anti-semitism within the Women's Movement, and the women of color claimed white racism.

Interestingly enough, some of the non-Jewish white women on the Spare Rib collective were able to acknowledge the multiple determinations involved. The white non-Jewish feminists were in a position to articulate a complex and ambivalent response to the situation, precisely because their "identities" were not interpolated into the situation as such. This is not to say that these women were not engaged in the issue-as members of the editorial collective, they struggled with and through their racism within the context of the controversy-but rather to suggest that the "politics of identity" in this particular experience were based primarily on ethnic and minority selfidentification. Because of this, many white feminists whose marks of "difference" (as Irish, lesbian, working class, etc.) were not emphasized within the conflict per se, were able to see how the other "identifications" circulated to produce the tangled knot of the antisemitism/anti-Zionism/racism debates. The Jewish women and women of color whose identities were directly hailed into the conflict experienced it as a threat to their identities; for each of these groups, the conflict was reduced to anti-semitism or racism, but not both. ${ }^{2}$

Identity politics has the potential to transform the "politics of experience" into a politics embedded in (and inextricable from) one's own particular experience, a kind of claustrophobia within identity. Identity is essentialized, and this leads to the difficulty of taking a position other than one which defends the "survival" of the identity as such; any threat to this survival is perceived as an attack on the validity of the group's history and its right to political self-determination. It was this turn toward identity politics, however, that brought attention to racism, anti-semitism, homophobia, and other forms of oppression within the Women's Movement in the first place and that subsequently gave rise to the analyses of difference between and among women that form the basis for much of the Movement's current struggles. To move away from identity politics altogether would be to ignore its significance within the history of "second wave" feminism and to deny the efficacy of such an approach in bringing attention to the needs and concerns of marginalized groups within any political movement. Identity politics needs to be retained as a possibility within feminism, as a provisional position-taking that acknowledges the 
historical legacies of and constraints upon those sub-groups that comprise the movement without locking its adherents into a totalizing over-identification with that history, an over-identification to which feminism must always pose a challenge.

Identity politics can survive as a politically progressive and useful positioning as long as we understand "identity" to signify a constructed positioning of the self within a specific historical conjuncture, and not an essentialized concept of the self that must survive at all costs. This is not to deny the real, historically appropriate fears that any group might have about its possibilities for survival as a group, but to suggest that those fears must be analyzed and understood within a perspective that questions the exclusion of difference upon which any sense of identity depends. If we conceive of politics as the process of taking up identities appropriate to given situations, as the forging of new identities through the process of active resistance, theory-making, and coalition building, then we can resist lapsing into essentialized identity formations that constrain the possibilities of our political struggles.

There are times when we must "call" our sisters on racist and anti-semitic behavior within feminism, but we must remember that the purpose of that kind of censure is the creation of alternative political identities. As feminists whose "identities" are constructed within different cultural and historical conjunctures, we need to learn how to use knowledge of these to facilitate our activism and to inform our behavior together as feminists committed to social change. There have been and will continue to be difficult and harsh conflicts within feminism, many of them inspired by racisms and other prejudicial behaviors, all of which need to be confronted and worked through. It is not my purpose here to smooth over the cracks and fissures of a "movement" as diverse and disparate as feminism. Neither is it my purpose to condemn the past political practices of the Spare Rib collective in terms of their struggle over racism, anti-semitism, and Zionism; to "blame" them for immature or inadequate political acumen would be to disregard their particular political circumstance and the historical conditions that produced it. I would like to think that not only can we "learn from the past," but that we can learn through it; that by thinking through the particulars of a given political conjuncture from the vantage point of our own, we can understand the ways in which previous categories of analysis have survived into the present and have stymied (both theoretical and activist) development in specific areas of political struggle. 


\section{NOTES}

1. The differences between the terms "oppression" and "exploitation" are not made particularly clear in Bourne's essay, although it is evident that she considers exploitation to define the material discrimination against and expropriation of surplus value from the worker of color. Oppression, through a lack of a specific definition, becomes associated with psychological forms of oppressive, inter-personal interactions. This polarization of terms is conceivably unnecessary, or at least, too simplistic. In addition, it ignores the ways in which feminist analysis has pointed to the politics of non-economic oppression that work to materially subordinate women within what are normally considered "non-economic" relations. In spite of this difficulty, her analysis of the shifting of focus from exploitation to oppression does point to the consequences of feminist analyses of racial oppression that deny or neglect to consider the implications of the economic system, and which lead to anti-racist work that concentrates wholly (or primarily) on racist "behavior."

2. It ought not be inferred here that the non-Jewish white women were therefore "clear" of any complicity in the way this issue unfolded within both the Spare Rib collective and the Movement as a whole. The point is not to hold them up as blameless - the point is not to blame anyone at all-but rather to know how (and possibly why) they were able to respond to the situation as they did. Certainly, non-Jewish white women in the Movement have been instrumental in turning the racism/anti-semitism debates into racism versus anti-semitism debates, thus enabling the construction of a situation where black and Jewish women confront each other about their respective prejudice, and maintaining the conflict over racial and ethnic discrimination as one between the already disadvantaged groups. While it would be foolish to ignore the non-Jewish white women's stake in keeping the debate circulating among black and Jewish women, it would also be foolish to ignore the ways in which "identity politics" limited the ways in which the black and Jewish women could struggle with each other on this issue.

\section{WORKS CITED}

Bourne, Jenny. "Homelands of the Mind: Jewish Feminism and Identity Politics." Race and Class 29.1 (1987): 1-24. Excerpted and reprinted as "Jewish Feminism and the Search for Identity." Spare Rib 184 (November 1987): 22-24.

Boyd, Roisin. "Women Speak Out Against Zionism." Spare Rib 121 (August 1982): 22-23.

Bulkin, Elly, Minnie Bruce Pratt, and Barbara Smith. Yours in Struggle: Three Feminist Perspectives on Anti-Semitism and Racism. Brooklyn: Long Haul P, 1984.

Editorial. Spare Rib 126 (January 1983): 4.

Editorial. Spare Rib 130 (May 1983): 4.

Editorial collective. "Sisterhood . . . is plain sailing." Spare Rib 132 (July 1983): 24-7.

Letters. Spare Rib 131 (June 1983): 26-27; Spare Rib 132 (July 1983): 4-5; Spare Rib 134 (September 1983): 44-46.

Pope, Juliet. "Anti-racism, Anti-Zionism, and Anti-Semitism: Debates in the British Women's Movement." Patterns of Prejudice 20.3 (1986): 13-25.

Tinker, Irene. "A Feminist View of Copenhagen" Signs 6 (1981): 531-37.

West London Jewish Lesbian Feminist Group. "About Anti-Semitism." Spare Rib 123 (October 1982): 20-21.

Women for Palestine. "Women Against Zionism." Spare Rib 124 (November 1982): 38-39. 
Yuval-Davis, Nira. "Zionism, Anti-Semitism, and the Struggle Against Racism: Some reflections on a painful debate among feminists." Spare Rib 148 (September 1984): 18-22. Reprinted in Connexions 19 (1986): 6-9.

\section{FURTHER READINGS}

Beck, Evelyn Torton, ed. Nice Jewish Girls. Watertown, MA: Persephone P, 1982.

Di Vilde Chayes. "An Open Letter to the Women's Movement." oob 12.6 (July 1982). (Di Vilde Chayes is a Jewish lesbian feminist group including Evelyn Torton Beck, Nancy Bereano, Melanie Kaye, Irena Klepfisz, Bernice Mennis, and Adrienne Rich.)

. "Zionists Deplore Killings in Lebanon and Criticize Nature of Anti-Israel Protests." oob 12.9 (October 1982): 27.

Heschel, Susannah, ed. On Being a Jewish Feminist: A Reader. New York: Schocken Books, 1983.

Koltun, Elizabeth, ed. The Jewish Woman: New Perspectives. New York: Schocken Books, 1976.

Letters. Big Mama Rag 9.1 (December 1981): 3.

Letters. oob 12.9 (October 1982): 28-29.

"Letters Forum: Anti-Semitism." Ms. February 1983: 12-18. (See especially the letter by Alice Walker.)

Martin, Biddy and Chandra Talpade Mohanty. "Feminist Politics: What's Home Got To Do With It?" Feminist Studies/Critical Studies. Ed. Teresa de Lauretis. Bloomington: Indiana UP, 1986. 191-212.

Nichols, Jill. "United Nations in Copenhagen." Spare Rib 98 (September 1980): 9-16.

Parker, Rozsika. "Being Jewish: Anti-Semitism and Jewish Women." Spare Rib 79 (February 1979): 27-31.

Pogrebin, Letty Cottin. "Anti-Semitism in the Women's Movement." Ms. June 1982: 45-49, 62-74.

Schneider, Susan Weidman. "Reconciling Jewish and Female." Jewish and Female: Choices and Changes in Our Lives Today. New York: Simon, 1984. 504-13.

Smith, Beverly, Judith Stein, and Priscilla Golding. "The Possibility of Life Between Us': A Dialogue Between Black and Jewish Women." Conditions: Seven (1981): 2546.

"Where We're At." Editorial. Big Mama Rag 9.1 (December 1981): 2, 21.

"Words From Nice Jewish Girls." Spare Rib 127 (February 1983): 20-23. 
